\title{
ANALISIS KEMAMPUAN BERPIKIR KRITIS MATEMATIS (BKM) SISWA SMP PADA MATERI SEGIEMPAT DAN SEGITIGA
}

\author{
Regiana Khulsum ${ }^{1}$, Yani Suryaningsih ${ }^{2}$, Marchasan Lexbin Evi Judah Riajanto ${ }^{3}$ \\ 1,2,3, IKIP Siliwangi, J1. Terusan Jendral Sudirman. Cimahi \\ 1'regiana.k@gmail.com, ${ }^{2}$ ayanish93@gmail.com, ${ }^{3}$ lexbin@stkipsiliwangi.ac.id
}

\begin{abstract}
This research is motivated by the importance of mathematic critical thinking ability for students and the low ability of students matematics critical thinking. The population in this study were all students of SMPN 2 Cimahi class VII, while the sample was students of class VII-7. Then through observation and interview determined 6 students as research subjects. The method used in this study is analytic descriptive. The research instrument is 5 essay questions that represent indicators of mathematic critical thinking ability. The results showed that the average achievement of students in each indicator was less than $50 \%$, which means it can be concluded that students' critical thinking skills are still relatively low.
\end{abstract}

Keywords: Mathematics critical thinking.

\begin{abstract}
Abstrak
Penelitian ini dilatarbelakangi oleh pentingnya kemampuan berpikir kritis matematis bagi siswa dan rendahnya kemampuan berpikir kritis matematis siswa. Populasi pada penelitian ini adalah seluruh siswa SMPN 2 Cimahi kelas VII, sedangkan sampelnya adalah siswa kelas VII-7. Kemudian melalui pengamatan dan observasi ditentukan 6 siswa sebagai subjek penelitian. Metode yang digunakan pada penelitian ini yaitu dekriptif analitik. Instrumen penelitian berupa 5 butir soal essay yang mewakili indikator kemampuan berpikir kritis matematis. Hasil penelitian menunjukan bahwa rata-rata pencapaian siswa pada setiap indikator adalah kurang dari 50\% yang berarti dapat disimpulkan bahwa kemampuan bepikir kritis matematis siswa masih tergolong rendah.
\end{abstract}

Kata kunci: Kemampuan berpikir kritis matematis.

How to cite: Khulsum, R., Suryaningsih, Y., Riajanto, M. L. E. J. (2018). Analisis Kemampuan Berpikir Kritis Matematis (BKM) Siswa SMP pada Materi Segiempat dan Segitiga. JPMI - Jurnal Pembelajaran Matematika Inovatif, 1 (5), 1015-1024.

\section{PENDAHULUAN}

Berpikir kritis yaitu kemampuan seseorang untuk merumuskan dan mengevaluasi keyakinan atau pendapatnya sendiri melalui tahapan atau proses yang sistematis (Hendriana, Rohaeti dan Soemarmo, 2007). Dalam matematika, berpikir matematik secara umum bisa diartikan sebagai aktivitas atau sistem matematika. Dilihat dari kedalamannya, berpikir matematik digolongkan menjadi berpikir tingkat rendah atau disebut low order thinking (LOT) dan berpikir tingkat tinggi atau disebut high order thinking (HOT) (Hendriana dan Soemarmo, 2007). LOW biasanya lebih mudah dimiliki ataupun dikembangkan oleh seseorang, namun tidak dengan HOT yang biasanya membutuhkan proses lanjut yang lebih luas dan dalam untuk dapat dimiliki ataupun dikembangkan. Dalam hal ini berpikir kritis matematis (BKM) termasuk kedalam katerogi HOT, banyak komponen yang digunakan baik memahami, 
menalar, menganalisis, memberi alasan, merefleksikan, menafsirkan, mencari hubungan, mengevaluasi bahkan membuat dugaan sementara. Berdasarkan hal tersebut BKM dapat didefinisikan sebagai kemampuan siswa menerima, menganalisis, memberikan penjelasan, menarik kesimpulan dan menyelesaikan suatu permasalahan matematika melalui langkah langkah yang tidak rutin.

Setiap orang dituntut memiliki kemampuan berpikir kritis, kreatif, logis, dan sistematis (Herman, 2007). Dari pernyataan tersebut berarti BKM memiliki fungsi yang substansial dalam aktivitas harian seseorang. Setiap individu membutuhkan kemampuan tersebut agar tidak dengan mudah menerima mentah-mentah informasi ataupun masalah, melainkan dapat menerima, memilah, mengolah, menganalisa, menyelesaikan dan mengevaluasi masalah ataupun informasi yang diterimanya tersebut. Selain itu, karena masalah yang semakin rumit dan bermacam-macam bentuk serta penyelesaiannya, juga kemajuan IPTEK yang pesat mengharuskan seseorang untuk dapat survive (bertahan) dan compete (bersaing).

Dalam pendidikan, berpikir kritis telah terbukti mempersiapkan peserta didik berpikir pada berbagai disiplin ilmu, menuju pemenuhan sendiri akan kebutuhan intelektual dan mengembangkan peserta didik sebagai individu berpotensi (Setiawan, 2015). Selain itu, Salah satu tujuan pembelajaran matematika adalah membentuk siswa yang berpikir ilmiah kritis dan mandiri (Mendiknas, 2006). Dalam hal ini dapat didefinisikan bahwa pembelajaran matematika tidak hanya berorientasi pada angka dan hitungan. Angka dalam pembelajaran matematika berperan sebagai sarana, hitungan senagai proses, namun pembelajarannya lebih dalam dari pada hal tersebut. Hal-hal tersebut menegaskan bahwa BKM memang penting untuk dimiliki dan dikembangkan oleh siswa. Melalui pembelajaran matematika, seharusnya siswa dapat memiliki kemampuan berpikir kritis yang baik. Kemampuan BKM ini diharapkan mampu membuat siswa bersikap rasional dan memilih alternatif pilihan yang terbaik bagi dirinya.

Beberapa studi terdahulu menemukan bahwa ternyata tingkat BKM siswa di Indonesia termasuk dalam kategori rendah. Berdasarkan hasil penelitian Syahbana (Novtiar dan Aripin, 2017) menunjukkan bahwa rata-rata kemampuan berpikir kritis matematis siswa SMP hanya 68 jika dalam skala 0-100, nilai ini baru termasuk dalam kategori cukup, yang berarti kemampuan berpikir kritis matematis siswa SMP masih termasuk rendah. Selain itu, Pada studi TIMSS (Trends in International Mathematics and Science Study) tahun 1999 dan studi PISA (Program for International Students Assessment) tahun 2003, diketahui bahwa high order thinking siswa di Indonesia tergolong rendah, termasuk critical thinking (Noer, 2009). Melihat hal-hal tersebut, maka dibutuhkan tindakan - tindakan yang nyata untuk melakukan improvement secara continue, agar kemampuan BKM siswa di Indonesia bisa ditingkatkan secara maksimal. Namun pada kenyaataan di lapangan upaya ataupun tindakan yang dilakukan untuk meningkatkan kemampuan BKM masih kurang, penyebabnya antara lain karena kurangnya kemampuan siswa, kemampuan tenaga pengajar, serta kurangnya fasilitas dan teknologi yang memadai.

BKM memang termasuk kemampuan yang kompleks, namun bukan berarti tidak dapat dikembangkan atau ditingkatkan. Menerapkan cara mengajar yang pas dan inovatif adalah salah satu alternatif pilihan untuk mengembangkan kemampuan BKM siswa. Tentunya bukan hal yang remeh atau ringan agar bisa memilih dan menerapkan metode atau cara mengajar yang sesuai, karena setiap individu siswa memiliki karakter dan cara berpikir yang berbedabeda. Setiap individu siswa adalah khas/unik dengan style learning yang khas pula (Lexbin, 2014). Hal tersebut sejalan dengan yang dikemukan Nurjaman dan Sari (2017) bahwa setiap siswa kemampuan bepikirnya tidak sama, ada perbedaan mindset yang disebabkan oleh 
background sekolah siswa. Berdasarkan hal-hal tersebut, maka faktor lain yang lebih penting lagi dalam upaya peningkatan kemampuan BKM adalah kemampuan intern dari siswa itu sendiri. Oleh karena itu, Sebelum dilakukan upaya pembenahan dan peningkatan, perlu untuk dilakukan analisis dan pengukuran terhadap kemampuan siswa agar dapat diketahui secara pasti tingkat kemampuan BKM siswa di lapangan. Selain itu,juga supaya bisa diketahui penyebab-penyebab dan kesulitan-kesulitan yang dihadapi siswa dalam menyelesaikan soal BKM yang menjadi penyebab dari kurangnya kemampuan BKM siswa.

Berdasarkan uraian diatas maka penulis berminat untuk melakukan analisis terhadap kemampuan BKM siswa SMP kelas VII di salah satu SMP Negeri di Cimahi Tengah pada materi segiempat dan segitiga.

\section{METODE}

Penelitian ini menggunakan metode deskriptif analitik. Dimana hasil penelitian dianalisis dan dideskripsikan untuk kemudian diambil kesimpulan secara umum. Populasi pada penelitian ini adalah seluruh siswa SMP Negeri 2 Cimahi. Sedangkan Sampel penelitian yaitu siswa kelas VII-7. Pengambilan sampel dengan cara melakukan wawancara kepada siswa. Setelah mempertimbangkan hasil wawancara, kemudian ditentukan 6 orang siswa sebagai subjek penelitian. Analisis data dilakukan menggunakan Microsoft exel 2010. Pengambilan data dilakukan melalui tes. Kemudian dilakukan penskoran terhadap jawaban siswa berdasarkan acuan pedoman penskoran kemampuan BKM dengan SMI (Skor Maksimum Ideal) adalah 4 untuk setiap butir soal. Instrument berupa 5 butir soal uraian yang mengukur kemampuan BKM dengan indikator sebagai berikut:

1. Memberikan penjelasan dengan menganalisis soal dan argument.

2. Mengembangkan keterampilan awal dengan melakukan observasi.

3. Menyimpulkan persoalan dengan melakukan deduksi.

4. Mengatur strategi penyelesaian masalah.

\section{HASIL DAN PEBAHASAN}

Hasil

Pengambilan data dilakukan melalui tes pada salah satu kelas VII di salah satu SMP Negeri yang ada di Kecamatan Cimahi Tengah, Kota Cimahi. Data dari hasil penelitian ini yaitu berupa hasil belajar siswa. Data tes diperoleh dari analisis jawaban siswa berdasarkan acuan pedoman penskoran kemampuan BKM dengan SMI (Skor Maksimum Ideal) adalah 4 untuk setiap butir soal. Berikut hasil yang diperoleh:

Tabel 1. Skor Jawaban Siswa pada Soal Nomor 1

\begin{tabular}{cc}
\hline Nomor urut Siswa & Jumlah Skor \\
\hline 001 & 2 \\
002 & 1 \\
003 & 1 \\
004 & 1 \\
005 & 2 \\
006 & 1 \\
Jumlah & $\mathbf{8}$ \\
Rata-rata & $\mathbf{1 . 3 3}$ \\
\hline
\end{tabular}




\section{Persentase (\%) $\quad 33.3 \%$}

Berdasarkan tabel 1 tersebut menujukan bahwa rata-rata skor yang diperoleh dari jawaban siswa untuk soal nomor satu dengan indikator memberikan penjelasan dengan menganalisis pertanyaan dan argumen adalah 1.33 dengan persentase pencapaian $33.3 \%$ yang berarti kemampuan siswa memberikan penjelasan dengan menganalisis pertanyaan dan argumen adalah rendah.

Tabel 2. Skor Jawaban Siswa pada Soal Nomor 2

\begin{tabular}{cc}
\hline Nomor Urut Siswa & Jumlah Skor \\
\hline 001 & 4 \\
002 & 2 \\
003 & 2 \\
004 & 2 \\
005 & 4 \\
006 & 4 \\
Jumlah & $\mathbf{1 8}$ \\
Rata-rata & $\mathbf{3}$ \\
\hline Persentase (\%) & $\mathbf{7 5 . 0 \%}$ \\
\hline
\end{tabular}

Berdasarkan tabel 3 tersebut menunjukan bahwa rata-rata skor yang diperoleh dari jawaban siswa untuk soal nomor satu dengan indikator mengembangkan keterampilan awal dengan melakukan observasi adalah 3 dengan persentase pencapaian 75\% yang berarti kemampuan mengembangkan keterampilan awal dengan melakukan observasi siswa adalah cukup.

Tabel 3. Skor Jawaban Siswa pada Soal Nomor 3 dan 4

\begin{tabular}{ccc}
\hline Nomor Urut Siswa & $\begin{array}{c}\text { Jumlah Skor } \\
\text { (Soal No.3) }\end{array}$ & $\begin{array}{c}\text { Jumlah Skor } \\
\text { (Soal No.4) }\end{array}$ \\
\hline 001 & 0 & 2 \\
002 & 1 & 1 \\
003 & 0 & 2 \\
004 & 0 & 2 \\
005 & 0 & 3 \\
006 & 1 & 4 \\
Jumlah & $\mathbf{2}$ & $\mathbf{1 4}$ \\
Rata-rata & $\mathbf{0 . 1 7}$ & $\mathbf{2 . 3 3}$ \\
\hline Persentase (\%) & $\mathbf{8 . 4 \%}$ & $\mathbf{5 8 . 3 \%}$ \\
\hline
\end{tabular}

Berdasarkan tabel 3 tersebut menunjukan bahwa rata-rata skor yang diperoleh dari jawaban siswa untuk soal nomor 3 dengan indikator menyimpulkan persoalan dengan melakukan deduksi adalah 0.17 dengan persentase pencapaian $8.4 \%$ yang berarti kemampuan mengembangkan keterampilan dasar dengan melakukan observasi siswa adalah sangat rendah. Sedangkan rata-rata skor yang diperoleh dari jawaban siswa untuk soal nomor 4 dengan indikator yang sama adalah 0.17 dengan persentase pencapaian $58.3 \%$ yang berarti 
kemampuan mengembangkan keterampilan dasar dengan melakukan observasi siswa adalah sedang.

Tabel 4. Skor Jawaban Siswa pada Soal Nomor 5

\begin{tabular}{cc}
\hline Kode Siswa & Jumlah Skor \\
\hline 001 & 1 \\
002 & 1 \\
003 & 2 \\
004 & 1 \\
005 & 0 \\
006 & 1 \\
Jumlah & $\mathbf{6}$ \\
Rata-rata & $\mathbf{1}$ \\
\hline Persentase (\%) & $\mathbf{2 5 \%}$ \\
\hline
\end{tabular}

Berdasarkan tabel 4 tersebut menunjukan bahwa rata-rata skor yang diperoleh dari jawaban siswa untuk soal nomor 5 dengan indikator mengatur strategi penyelesaian masalah adalah 0.17 dengan persentase pencapaian $25 \%$ yang berarti kemampuan mengembangkan keterampilan dasar dengan melakukan observasi siswa adalah rendah.

Secara keseluruhan rata-rata pencapaian siswa dalam menyelesaikan soal kemampuan berpikir kritis matematis adalah $40 \%$, yang berarti termasuk rendah.

\section{Pembahasan}

Berdasarkan hasil penelitian diketahui bahwa kemampuan siswa memberikan penjelasan dengan menganalisis soal dan argument termasuk rendah, kemampuan siswa megembangkan keterampilan awal dengan melakukan observasi termasuk sedang, kemampuan siswa menyimpulkan persoalan dengan melakukan deduksi termasuk sedang, dan kemampuan siswa mengatur strategi penyelesaian masalah termasuk sangat rendah. Dengan demikian dapat dikatakan bahwa kemampuan perpikir kritis siswa termasuk rendah. Hal tersebut sesuai dengan hasil penelitian Syahbana (Novtiar dan Aripin, 2017) yang menunjukkan bahwa kemampuan berpikir kritis matematis siswa SMP masih termasuk rendah.

Untuk mengetahui kesulitan-kesulitan yang dialami siswa dalam menyelesaikan soal-soal kemampuan berpikir kritis, maka dialkukan analisis terhadap jawaban siswa. Berikut analisis dari sampel jawaban siswa pada setiap indikator:

\section{Indikator Memberikan Penjelasan dengan Menganalisis Soal dan Argument}

Indikator memberikan penjelasan dengan menganalisis soal dan argument ini terdapat pada soal nomor 1, yaitu sebagai berikut:

Berdasarkan sisi-sisinya segitiga dibagi menjadi 3 jenis, yaitu segitiga sama sisi, segitiga sama kaki, dan segitiga sembarang. Sedangkan berdasarkan besar sudutnya, segitiga dibagi menjadi 3 jenis yaitu segitiga lancip, segitiga siku-siku dan segitiga tumpul. Menurutmu, benarkah jika segitiga sama kaki, segitiga sama sisi, dan segitiga sembarang merupakan segitiga lancip? jelaskan!

Sampel Jawaban siswa untuk soal nomor 1 terdapat pada gambar berikut: 


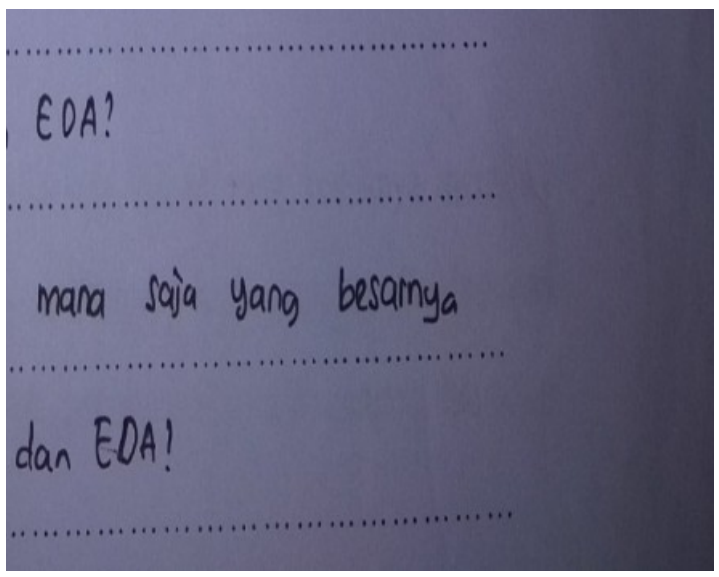

\section{Gambar 1}

Pada Gambar 1 menunjukan bahwa siswa menjawab iya dan memberikan penjelasan yang tidak lengkap serta tidak logis. Keterangan yang siswa berikan sebagai penjelasannya tidak berdasarkan materi yang berkaitan dengan sifat - sifat ataupun pengertian dari segitiga lancip itu sendiri. Pada indikator ini rata-rata presentase siswa hanya mencapai 33.3\% menandakan sebagian besar tidak siswa mampu menjawab pertanyaan dengan benar. Wawancara terhadap siswa mendeskripsikan bahwa siswa mampu menjawab pertanyaan, namun tidak mampu memberikan penjelasan yang logis berdasarkan materi yang dipelajari karena mereka mereka tidak memahami penjelasan seperti apa yang dimaksudkan di dalam soal.

\section{Indikator Mengembangkan Keterampilan Awal dengan Melakukan Observasi.}

Indikator mengembangkan keterampilan awal dengan melakukan observasi terdapat pada soal nomor 2, yaitu sebagai berikut:

Perhatikan gambar berikut!

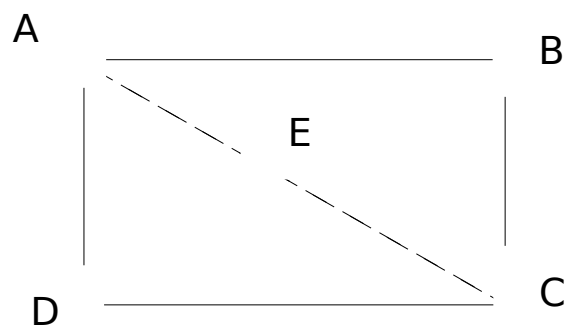

\section{Gambar 2}

Dilihat dari gambar diatas, jika besar sudut DEC adalah $120^{\circ}$ dan besar sudut EDC adalah $30^{\circ}$.

a. Berapakah Besar sudut DEA dan EDA?

b. Dapatkah kamu menunjukan sudut mana sajakah yang besarnya sama dengan sudut DEA dan sudut EDA?

Sampel Jawaban siswa untuk soal nomor 2 terdapat pada gambar berikut: 


\section{Gambar 3}

Pada gambar 2 menunjukan bahwa siswa dapat menghitung ukuran salah satu sudut dengan benar dan dapat menunjukan sudut-sudut yang memiliki ukuran yang sama. Pada indikator soal mengembangkan keterampilan awal ini siswa rata-rata mencapai presentase sebesar $75 \%$ yang menandakan kemampuan siswa pada indikator ini cukup tinggi. Wawancara terhadap siswa mendeskripsikan bahwa siswa mampu menjelaskan cara mereka menghitung besar sudut yang belum diketahui dan menunjukan sudut-sudut lainnya yang memiliki ukuran yang sama, namun masih terdapat sedikit kesalahan yang dikarenakan siswa sendiri kurang teliti dalam melihat gambar dan membaca soal.

\section{Indikator Menyimpulkan Persoalan dengan Melakukan Deduksi.}

Indikator menyimpulkan persoalan dengan melakukan deduksi terdapat pada soal nomor 3 dan 4, yaitu sebagai berikut:

\section{a. Soal Nomor 3}

Belah ketupat dan jajar genjang merupakan segi empat yang keduanya memiliki empat buah sisi dimana sisi yang saling berhadapan sama panjang. Berdasarkan pernyataan tersebut, benarkah setiap belah ketupat adalah jajar genjang dan begitu pula sebaliknya?

\section{b. Soal Nomor 4}

Persegi panjang memiliki sisi dan sudut masing-masing sebanyak 4 buah. Berdasarkan pernyataan tersebut dapatkah kamu memeriksa pernyataan berikut:

a) Jika persegi ukuran kedua sisi yang berhadapan sama panjang, cukupkah pernyataan tersebut untuk menggambarkan persegi panjang?

b) Jika persegi panjang keempat buah sudutnya sama besar, cukupkah pernyataan tersebut untuk menggambarkan persegi panjang?

c) Apa yang kamu bisa simpulkan mengenai persegi panjang berdasarkan pernyataan a dan b diatas? Jelaskan!

Sampel jawaban siswa untuk soal nomor 3 dan 4 terdapat pada gambar berikut: 


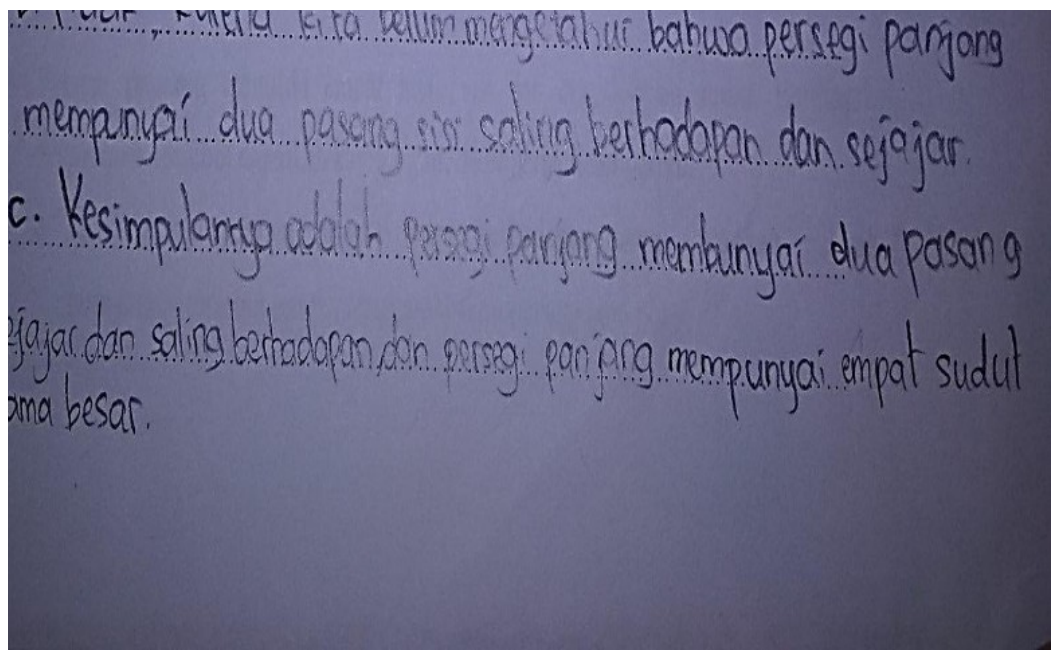

\section{Gambar 4}

Pada gambar 3 menunjukan bahwa siswa tidak bisa memberikan kesimpulan yang benar dari pernyataan yang diberikan pada soal. Siswa juga tidak bisa memberikan penjabaran yang rasional berkaitan dengan sifat dan unsur dari belah ketupat dan jajar genjang. Sedangkan pada soal nomor 4 siswa dapat menjawab dengan cukup baik, siswa dapat menarik kesimpulan berdasarkan pertanyaan - pertanyaan sebelumnya, hanya saja siswa belum bisa menjelaskan dengan tepat. Pada indikator menyimpulkan persoalan ini siswa rata-rata mencapai presentase sebesar $8.4 \%$ dan $58.43 \%$ yang menandakan kemampuan siswa menjawab soal dengan indikator ini kurang. Wawancara terhadap siswa mendeskripsikan bahwa siswa mampu menjelaskan sifat-sifat segiempat persegi, persegipanjang, belah ketupat dan jajar genjang secara terpisah, namun siswa tidak bisa membandingkan ataupun menghubungkan sifat antar bangun datar satu dengan yang lainnya.

\section{Indikator Mengatur Strategi Penyelesaian Masalah.}

Indikator mengatur strategi penyelesaian masalah terdapat pada soal nomor 5, yaitu sebagai berikut:

Diketahui sebuah segitiga $\mathrm{ABC}$, dengan panjang sisi $\mathrm{AB}$ adalah $5 \mathrm{~cm}$ dan panjang sisi $\mathrm{AC}$ adalah $3 \mathrm{~cm}$. Jika diketahui besar sudut BAC adalah $60^{\circ}$. Dapatkah kamu mengetahui luas dan keliling segitiga tersebut?

Sampel jawaban siswa untuk soal nomor 5 terdapat pada gambar berikut: 


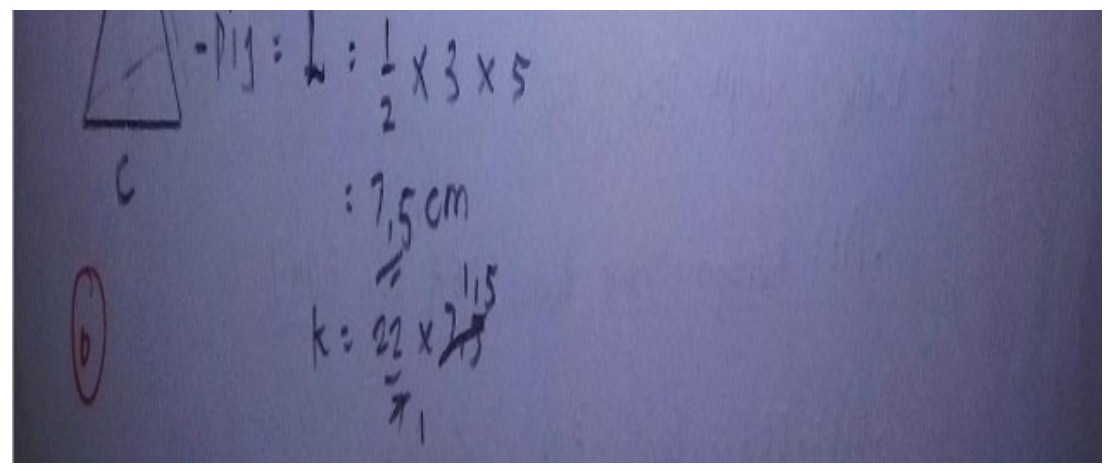

Gambar 5

Pada gambar 4 menunjukan bahwa siswa tidak dapat menghitung dengan benar, siswa seharusnya mencari tahu dulu panjang satu sisi segitiga lain yang tidak ada pada soal agar dapat menghitung luas dan kelilingnya, Namun siswa langsung menghitung berdasarkan panjang sisi yang diketahui di soal saja. Pada indikator mengatur strategi ini siswa mampu menjawab dengan rata-rata presentase sebesar $25 \%$ ini menandakan kemampuan siswa pada menjawab soal indikator ini rendah. Wawancara terhadap siswa mendeskripsikan bahwa siswa tidak mengetahui bagaimana cara mencari panjang sisi yang diketahui, jadi siswa menghitung dengan data seadanya.

Dari analisis jawaban siswa diketahui bahwa siswa masih mengalami kesulitan dalam menyelesaikan soal kemampuan BKM, salah satu yang menyebabkan rendahnya kemampuan BKM siswa. Kesulitan-kesulitan tersebut diantaranya yaitu siswa tidak terbiasa dengan bentuk soal non-rutin (siswa tidak terbiasa melakukan observasi, analisis, dan deduksi), siswa kurang dalam pemahaman soal dan materi, siswa kurang teliti dalam mengerjakan soal. Kesulitankesulitan ini seharusnya bisa diatasi melalui kegiatan belajar mengajar yang tepat sasaran, kebiasaan belajar matematika yang tidak sekedar hafalan rumus dan hitungan, tetapi juga pemahaman dan penalaran mengenai konsep matematika. Hal tersebut dapat membantu siswa untuk membangun kemampuan berpikir matematik yang lebih dalam, termasuk BKM.

\section{KESIMPULAN}

Berdasarkan hasil dan pembahasan diketahui bahwa kemampuan BKM siswa SMP kelas VII pada materi segiempat dan segitiga termasuk rendah. Dilihat dari rata-rata presentase pencapaian semua indikator, hanya satu dari empat indikator yang dapat dicapai oleh sebagian besar siswa, yaitu indikator mengembangkan keterampilan awal dengan melakukan observasi dan mempertimbangkan hasil observasi. Sedangkan pada Indikator lainnya yaitu memberikan penjelasan sederhana dengan memfokuskan pada pertanyaan, menganalisis argumen, menyimpulkan persoalan dengan melakukan dan mempertimbangkan deduksi, dan mengatur strategi penyelesaian masalah, sebagian besar siswa tidak mampu mencapai indikator tersebut.

\section{DAFTAR PUSTAKA}

Hendriyana, H. \& Sumarmo, U. (2014). Penilaian Pembelajaran Matematika. Bandung: Refika Aditama.

Hendriana, H., Rohaeti, E. E., \& Sumarmo, U. (2017). Hard Skills dan Soft Skills Matematik 
1024Khulsum, Suryaningsih, Riajanto, Analisis Kemampuan Berpikir Kritis Matematis....

Siswa. Bandung: Refika Aditama.

Herman, T. (2007). Pembelajaran Berbasis Masalah untuk Meningkatkan Kemampuan Berpikir Matematis Tingkat Tinggi Siswa Sekolah Menengah Pertama. Jurnal Educationist, I(I), 47-56.

Lexbin, M. (2014). Pengembangan Pembelajaran Era Post Modern Menuju Ketercapaian Kemampuan Matematis Siswa. Jurnal Infinity, 3(1), 81-100.

Mendiknas. (2006). Peraturan Menteri Pendidikan Nasional Republik Indonesia Nomor 22 tahun 2006. Jakarta: Kementrian Pendidikan Nasional.

Noer, S. H. (2009). Peningkatan Kemampuan Berpikir Kritis Matematis Siswa SMP melalui Pembelajaran Berbasis Masalah. Prosiding elektronik Seminar Nasional Matematika dan Pendidikan Matematika FMIPA UNY, 473-483.

Novtiar, C. \& Aripin, U. (2017). Meningkatkan Kemampuan Berpikir Kritis Matematis dan Kepercayaan Diri Siswa SMP melalui pendekatan Open Ended. Jurnal Prisma, 6(2), 119131.

Nurjaman, A. \& Sari, I. P., (2017). The Effect of Problem Posing Approach towards Studets Mathematical Disposision, Critical \& Creative Thinking Ability Based on School Level. Junral Infinity, 6(1), 69-76.

Setiawan, W. (2015). Meningkatkan Kemampuan Berpikir Kritis Matematis Siswa SMP dengan menggunakan Model Penemuan Terbimbing. Jurnal UPT P2M STKIP Siliwangi, 2(1), 91-96. 